\title{
Coronary artery bypass surgery prior to resection of abdominal aortic aneurysm in patients with unstable coronary artery disease
}

\author{
GLENN E. HAAS, DO \\ GRANT VAN S. PARR, MD \\ W. CLARK HARGROVE, MD \\ ROBERT G. TROUT, MD
}

\section{Coronary artery disease} (CAD) is associated with abdominal aortic aneurysm in greater than $60 \%$ of cases. CAD continues to affect postoperative complication rates. Half of the deaths that follow resection of abdominal aortic aneurysms are due to perioperative myocardial infarctions. On evaluation for surgical resection of an abdominal aortic aneurysm, six patients were found to have significant CAD. Each underwent coronary artery bypass surgery prior to elective resection of the aneurysm. No deaths or myocardial infarctions occurred following any of the procedures. We restrict our indications for coronary angiography to the evaluation of patients with unstable angina (pain at rest or after minimal exertion) in whom noninvasive studies reveal evidence of CAD, and for patients who are unresponsive to medical management.

Atherosclerosis is a systemic disease that steadily progresses to end organ symptoms. The simultaneous occurrence of coronary artery disease (CAD) and abdominal aortic aneurysm approaches $60 \% .^{1,2}$ Myocardial infarction (MI) is the leading cause of death following the resection of such aneurysms. ${ }^{3-5}$ Patients with a history of CAD or previous MI also have increased risk of surgical morbidity. ${ }^{6,7}$

The evaluation of patients with abdominal aortic aneurysms should include a precise cardiac his- tory. We also believe that patients who have significant CAD and angina that is not well controlled with medical therapy should undergo cardiac catheterization. For patients at greatest risk, coronary artery bypass surgery (CABS) prior to vascular resection affords myocardial protection during the perioperative period. Patients should be evaluated on an individual basis. When appropriate, CABS should be performed six to eight weeks prior to the resection of the aneurysm. Our success and the results that appear in the literature have encouraged us to continue this approach.

\section{Patient selection and results}

Six male patients ranging in age from 56 to 69 years were evaluated for abdominal aortic aneurysm; all had significant CAD. In all patients, angiography confirmed the presence of the aneurysms, which had been detected on routine physical examination. The aneurysms measured 8 to $10 \mathrm{~cm}$ in their greatest diameters. All patients had unstable angina, either at rest or after minimal exertion. Four patients had a history of MI. In one (patient 4), MI followed an episode of hemorrhage from an active duodenal ulcer. Four patients had positive stress ECGs. At cardiac catheterization, all six patients were found to have triple vessel disease, and patients 4 and 6 had occlusion of the left main coronary artery (Table 1 ).

CABS was performed six to eight weeks before vascular resection for five patients; at his own request, aneurysmorrhaphy was delayed for one year for patient 2. CABS was accomplished with reversed saphenous vein grafts and cold potassium 
TABLE 1. CARDIAC HISTORIES AND CATHETERIZATION RESULTS FOR SIX MALE PATIENTS WHO HAD ELECTIVE RESECTION OF ABDOMINAL AORTIC ANEURYSMS (AAA) WITH 100\% POSTOPERATIVE SURVIVAL.

\begin{tabular}{|c|c|c|c|c|c|c|c|c|}
\hline \multirow[b]{2}{*}{ Patient } & \multirow[b]{2}{*}{$\begin{array}{l}\text { Age } \\
(\mathrm{yr})\end{array}$} & \multirow[b]{2}{*}{ CAD symptoms } & \multirow[b]{2}{*}{ ECG } & \multirow[b]{2}{*}{$\begin{array}{l}\text { Medical } \\
\text { therapy }\end{array}$} & \multicolumn{2}{|c|}{ Catheterization data } & \multirow[b]{2}{*}{$\mathrm{CAD}$ surgery } & \multirow[b]{2}{*}{ AAA surgery } \\
\hline & & & & & Artery & $\%$ Block & & \\
\hline 1 & 56 & Angina, dyspnea & $\begin{array}{l}\text { Nonspecific } \\
\text { ST segment } \\
\text { changes }\end{array}$ & $\begin{array}{c}\text { Verapamil, } \\
\text { digoxin }\end{array}$ & $\begin{array}{l}\text { LAD } \\
\text { LCx } \\
\text { LCx Mg } \\
\text { RCA } \\
\text { RV Br }\end{array}$ & $\begin{array}{r}100 \\
90 \\
80 \\
100 \\
90\end{array}$ & CABS 5 & $\begin{array}{l}\text { 9-cm AAA, } \\
22 \text {-mm aortoiliac } \\
\text { bifurcation } \\
\text { graft }\end{array}$ \\
\hline 2 & 66 & $\begin{array}{l}\text { Angina, dyspnea, } \\
\text { previous MI, HBP, } \\
\text { positive stress test }\end{array}$ & $\begin{array}{l}\text { LAHB, } \\
\text { old MI }\end{array}$ & $\begin{array}{l}\text { Aldomet, NTG, } \\
\text { procainamide, } \\
\text { digoxin }\end{array}$ & $\begin{array}{l}\text { LMain } \\
\text { LCx Mg } \\
\text { RCA }\end{array}$ & $\begin{array}{r}100 \\
60 \\
50\end{array}$ & CABS 3 & $\begin{array}{l}\text { 8-cm AAA, } \\
\text { 19-mm aortoiliac } \\
\text { bifurcation } \\
\text { graft }\end{array}$ \\
\hline 3 & 68 & $\begin{array}{l}\text { Angina, dyspnea } \\
2 \text { previous MIs, } \\
\text { HBP }\end{array}$ & $\begin{array}{l}\mathrm{Q} \text { (II,III), } \\
\mathrm{Q} \text { (AVF) }\end{array}$ & $\begin{array}{l}\text { Inderal, NTG, } \\
\text { Procardia, } \\
\text { digoxin }\end{array}$ & $\begin{array}{l}\text { LAD } \\
\text { LCx Mg } \\
\text { Interm } \\
\text { RCA }\end{array}$ & $\begin{array}{r}100 \\
80 \\
100 \\
100\end{array}$ & $\begin{array}{l}\text { CABS } 6 \\
\text { resection LV } \\
\text { aneurysm }\end{array}$ & $\begin{array}{l}\text { 8-cm AAA, } \\
22 \text {-mm aortoiliac } \\
\text { bifurcation } \\
\text { graft }\end{array}$ \\
\hline 4 & 69 & $\begin{array}{l}\text { MI (GI bleeding) } \\
\text { positive stress test }\end{array}$ & $\begin{array}{l}1^{\circ} \mathrm{AV} \\
\text { block, LVH }\end{array}$ & $\begin{array}{l}\text { Procardia, } \\
\text { NTG }\end{array}$ & $\begin{array}{l}\text { LMain } \\
\text { LAD } \\
\text { LAD Dg } \\
\text { RCA }\end{array}$ & $\begin{array}{r}90 \\
85 \\
90 \\
100\end{array}$ & CABS 6 & $\begin{array}{l}\text { 10-cm AAA, } \\
\text { 22-mm straight } \\
\text { graft }\end{array}$ \\
\hline 5 & 66 & $\begin{array}{l}\text { Hypotensive, previous } \\
\text { laparotomy, HBP, } \\
\text { positive stress test }\end{array}$ & $\begin{array}{l}\text { Nonspecific } \\
\text { ST segment } \\
\text { changes, } \\
\text { T wave inversion. }\end{array}$ & $\begin{array}{l}\text { Aldomet, } \\
\text { insulin, } \\
\text { Timolol }\end{array}$ & $\begin{array}{l}\text { LAD } \\
\text { LCx Mg } \\
\text { LAD Dg } \\
\text { RCA }\end{array}$ & $\begin{array}{r}90 \\
80 \\
75 \\
100\end{array}$ & CABS 4 & $\begin{array}{l}\text { 9-cm AAA, } \\
20 \text {-mm straight } \\
\text { graft }\end{array}$ \\
\hline 6 & 69 & $\begin{array}{l}\text { Angina, HBP, } \\
\text { previous MI }\end{array}$ & $\begin{array}{l}\text { Atrial fibrillation, } \\
\text { old MI, T wave } \\
\text { inversion }\end{array}$ & $\begin{array}{l}\text { Digoxin, } \\
\text { Tolinase, } \\
\text { Procardia }\end{array}$ & $\begin{array}{l}\text { LMain } \\
\text { LAD } \\
\text { RCA }\end{array}$ & $\begin{array}{r}90 \\
90 \\
100\end{array}$ & CABS 3 & $\begin{array}{l}\text { 8-cm AAA, } \\
20 \text {-mm aortoiliac } \\
\text { bifurcation } \\
\text { graft }\end{array}$ \\
\hline
\end{tabular}

$\overline{\mathrm{CAD}}=$ coronary artery disease; $\mathrm{MI}=$ myocardial infarction $; \mathrm{HBP}=$ high blood pressure; $\mathrm{GI}=$ gastrointestinal LAHB $=$ left anterior hemiblock; $\mathrm{AVF}=$ atrioventricular

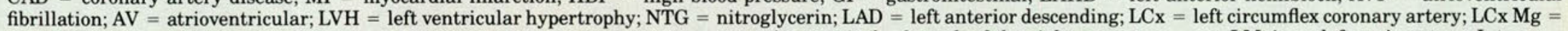

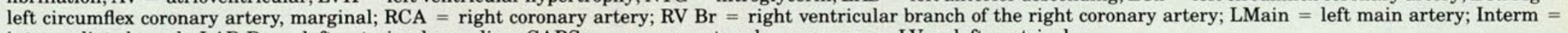
intermediate branch; $\mathrm{LAD} \mathrm{Dg}=$ left anterior descending; CABS = coronary artery bypass surgery; $\mathrm{LV}=$ left ventricular. 


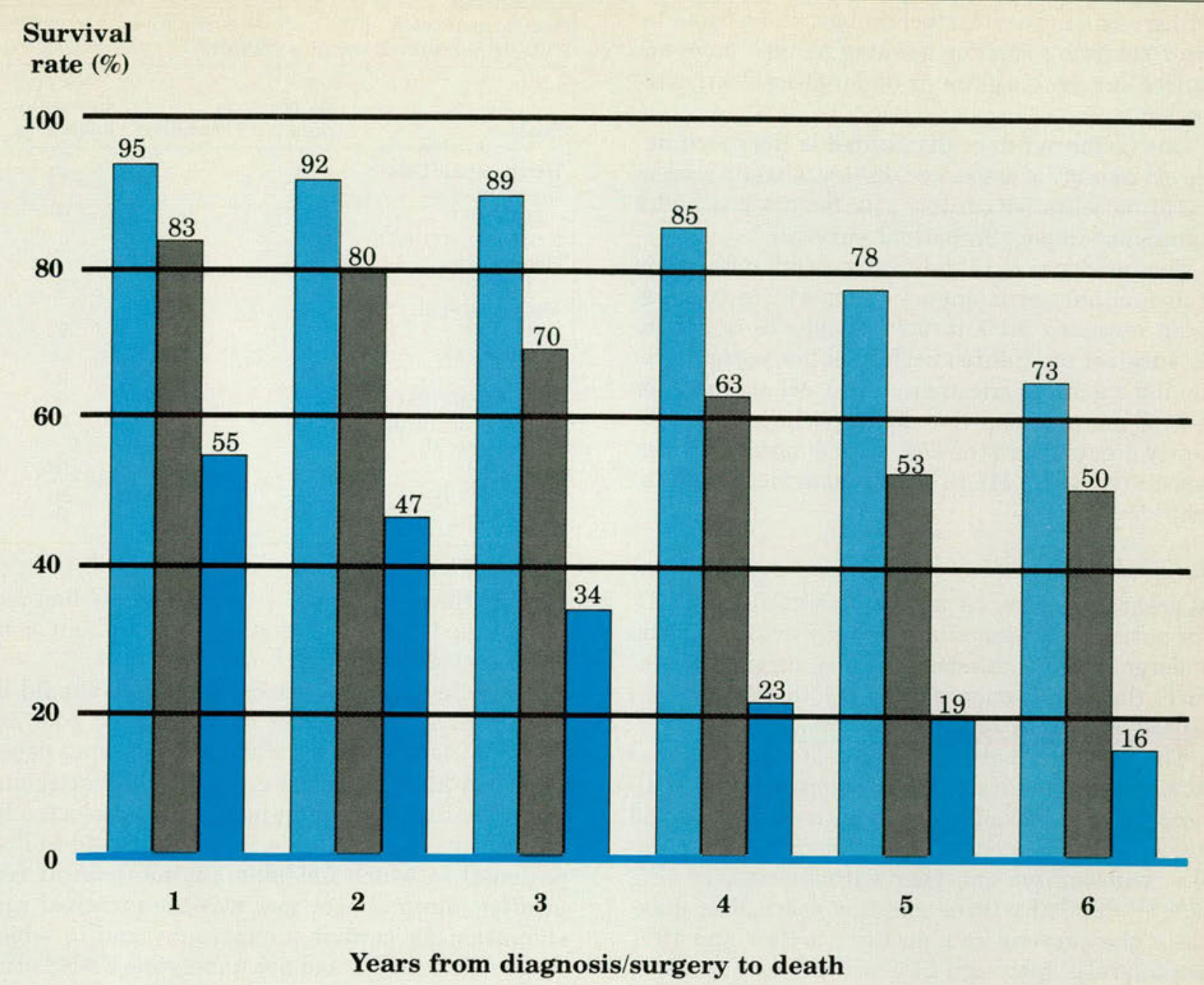

Normal population adjusted for age $\mathrm{e}^{33}$

Survival for patients with surgical resection of AAA including operative mortalities $8,14,16-20,23,24,27,30-35$

Survival of patients with AAA without surgery $8,23-32,36$

Fig 1. Survival rates of patients with and without surgical resection of abdominal aortic aneurysms, from time of diagnosis or surgery to death.

cardioplegia. After systemic heparinization, patients underwent aneurysmorrhaphy with woven Dacron grafts. All of the procedures were performed on an elective basis.

Following the operative procedures, the patients received appropriate intensive care monitoring. Pneumonia developed in patient 6 subsequent to resection. He had no other postoperative complication during recovery. The other patients had no significant complications postoperatively, and none of the patients had ECG changes after surgery. All patients are alive and well at this time of the writing of this article.

\section{Discussion}

\section{Mortality rates}

Over the past 30 years, the mortality rates for elective resection of abdominal aortic aneurysms have declined from approximately $15 \%$ during the early years (1950s) to $3 \%$ to $5 \%$ at present.

Several reviews illustrate the progressive improvement in mortality rates. ${ }^{8-15}$

Improvements in fluid management, precise perioperative hemodynamic monitoring, and newer anesthetic agents have helped to minimize operative mortality. Improvements in prosthetic materials, 
refinements in surgical techniques, and a trend toward resecting smaller aneurysms also have enhanced survival in patients undergoing elective resection.

One factor not to be discounted is the much improved therapy of associated disease. Careful screening of patients for cardiac risk factors has had a significant impact on patient survival.

The incidence of MI following elective resection of abdominal aortic aneurysms is $4 \%$, in contrast to an expected $0.1 \%$ to $0.7 \%$ incidence of $\mathrm{MI}$ for all surgical procedures performed for patients receiving a general anesthetic. Also, MI accounts for $50 \%$ of the postoperative deaths, which is significantly greater than the $15 \%$ to $20 \%$ mortality rates associated with MI in the nonsurgical population. ${ }^{1,3,6,10-14,16-21}$

\section{Surgical risk}

At greatest risk are patients with significant CAD. For patients who have survived a previous MI who undergo general anesthesia for a surgical procedure, the reinfarction rate is $6 \%$ to $7 \%$, with an expected mortality rate of $65 \% .^{22}$

The unresected abdominal aortic aneurysm also carries a high mortality rate. From the time of diagnosis, only $55 \%$ of patients with aneurysms $\geqslant 5$ $\mathrm{cm}$, as demonstrated on plain abdominal radiography, will survive one year without surgery (Fig 1). 8,14,16-20,23-36 By three and five years after diagnosis, the survival rate declines to $34 \%$ and $19 \%$, respectively. Although $21 \%$ will die as a result of MI, $30 \%$ will die of a ruptured aneurysm. The mortality rate for ruptured abdominal aortic aneurysms requiring emergency surgery is approximately $50 \%$. Without surgery, ruptured aneurysms invariably prove fatal.

In the past, many patients with advanced CAD had been refused surgery for abdominal aortic aneurysm. However, after the first postoperative year, survival rates for these patients who have undergone resection approaches that of the normal, agerelated population (Fig 1). The three- and fiveyear survival rates for patients who have resected aneurysms [v] those for patients with unresected aneurysms $(70 \%$ [v] $34 \%$ and $53 \%$ [v] 19\%, respectively) clearly demonstrate the benefit of elective surgical resection of abdominal aortic aneurysms.

\section{Presurgical evaluation}

How extensive should the investigation of CAD be? Several vascular surgical centers perform simultaneous cardiac and abdominal aortic angiography. At the Cleveland Clinic, preoperative cardiac catheterization revealed triple-vessel CAD in $31 \%$ of 91 patients who had no clinical indication of

\begin{tabular}{|c|c|c|c|}
\hline Study & $\begin{array}{l}\text { No. of } \\
\text { cases }\end{array}$ & Mortality & $\begin{array}{c}\text { No. of } \\
\text { myocardial } \\
\text { infarctions }\end{array}$ \\
\hline Hertzer et al $(1984)^{5}$ & 61 & 1 & $\ldots$ \\
\hline $\begin{array}{l}\text { Crawford et al } \\
\qquad(1978)^{38}\end{array}$ & 49 & 0 & 0 \\
\hline Kramer et al $(1982)^{1}$ & 29 & 0 & 0 \\
\hline $\begin{array}{l}\text { Hertzer et al } \\
(1979)^{39}\end{array}$ & 21 & 0 & 0 \\
\hline McCollum et al & 17 & 0 & 0 \\
\hline $\begin{array}{l}\text { Edwards et al } \\
(1978)^{4}\end{array}$ & 9 & 0 & 0 \\
\hline Brown et al $(1981)^{6}$ & 6 & 0 & 0 \\
\hline Chang et al $(1978)^{21}$ & 3 & 0 & 0 \\
\hline $\begin{array}{l}\text { Szarnicki et al } \\
\qquad(1971)^{41}\end{array}$ & 2 & 0 & 0 \\
\hline $\begin{array}{l}\text { Present study } \\
\text { Total }\end{array}$ & $\frac{6}{203}$ & $\frac{0}{1}$ & $\frac{0}{0}$ \\
\hline
\end{tabular}

CAD. ${ }^{36}$ However, none of these patients had disease of the left main coronary artery without some clinical evidence of CAD.

We believe that electrocardiography should be performed routinely, and we find gated pool nuclear (MUGA) scanning with cardiac output determination helpful. Stress electrocardiography and stress thallium scanning may be done selectively.

Reports from two large series $\left(422^{6}\right.$ and $517^{9}$ of patients) in which unstable angina (pain at rest or after minimal exertion) was the principal consideration for cardiac angiography and in which nearly all patients had not undergone CABS prior to aneurysm resection, overall mortality was $1.7 \%$ (7 deaths, 4 from MI) and 2.3\% (12 deaths, 9 from MI), respectively.

\section{Conclusions}

We believe that these mortality rates are acceptable, but we do not believe that proceeding with CABS in patients with CAD who are clincally asymptomatic would provide any significant benefit, especially in view of the $3 \%$ to $5 \%$ mortality attendant to CABS.

We further believe that coronary angiography (and CABS) is unnecessary in patients with CAD who have their disease well controlled on a medical regimen, who have no significant past cardiac history, and who have normal findings on noninvasive cardiac evaluation.

Advanced CAD should not serve routinely as a contraindication to aneurysmorrphaphy. CABS may be performed with an acceptable degree of safety. Review of the literature confirms that CABS prior to resection of abdominal aortic aneurysms affords excellent myocardial protection (Table 2) $1,4-6,21,38-41$. 
The \#1 prescribed allergy in the U.S. and worldwide 


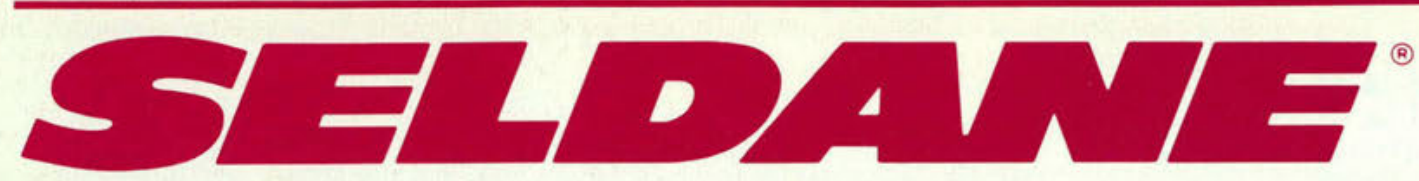

\section{(terfenadine) $60 \mathrm{mg}$ tablets BID}

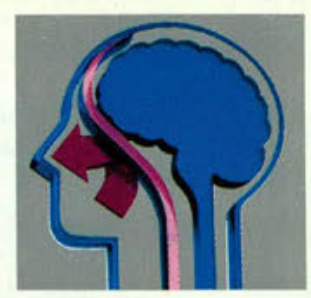

\section{- Fast, unsurpassed relief}

Efficacy maintained with through-the-season use - B.i.d. dosing for high patient compliance - High patient preference

\section{- Lets patients stay alert so they can perform at their best}

\section{Seldane ${ }^{\circledR}$ (terfenadine) $60 \mathrm{mg}$ Tablets \\ BRIEF SUMMARY}

CAUTION: Federal law prohibits dispensing without prescription.

DESCRIPTION

Seldane (terfenadine) is available as tablets for oral administration. Each tablet contains $60 \mathrm{mg}$ terfenadine. Tablets also contain, as inactive ingredients: corn starch, gelatin, lactose, magnesium stearate, and sodium bicarbonate.

\section{INDICATIONS AND USAGE}

Seldane is indicated for the relief of symptoms associated with seasonal allergic minitis such as sneezing, rhinorrhea, pruritus, and lacrimation.

CONTRAINDICATIONS

Seldane is contraindicated in patients with a known hypersensitivity to terfenadine or any of its ingredients.

\section{PRECAUTIONS}

Information for patients

Patients taking Seldane should receive the following information and instructions. Antihistamines are prescribed to reduce allergic symptoms. Patients should be questioned about pregnancy or lactation before starting Seldane therapy, since the drug should be used in pregnancy or lactation only if the potential benefit justifies the potential risk to tetus or baby. Patients should be instructed to take Seldane

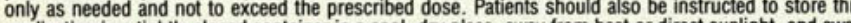
medication in a tightly closed container in a cool, dry place, away from heat or direct sunilight, and away from children.

Carcinogenesis, mutagenesis, impairment of fertility Oral doses of terfenadine, corresponding to 63 times the recommended human daily dose, in mice for 18
months or in rats for 24 months, revealed no evidence of tumorigenicity. Microbial and micronucleus months or in rats for 24 months, revealed no evidence of tumorigenicity.

test assays with terfenadine have revealed no evidence of mutagenesis. to 21 times the human daily dose. At 63 times the human daily dose there was a small but significan reduction in implants and at 125 times the human daily dose reduced implants and increase post-implantation losses were observed, which were judged to be secondary to maternal toxicity.

Pregnancy Category C

There was no evidence of animal teratogenicity. Reproduction studies have been performed in rats at doses 63 times and 125 times the human daily dose and have revealed decreased pup weight gain and survival when terfenadine was administered throughout pregnancy and lactation. There are no adequate and well-controlled studies in pregnant women. Seldane should be used during pregnancy only if the potential benefit justifies the potential risk to the fetus.

Nonteratogenic effects

Seldane is not recommended for nursing women. The drug has caused decreased pup weight gain and survival in rats given doses 63 times and 125 times the human daily dose throughout pregnancy and lactation. Effects on pups exposed to Seldane only during lactation are not known, and there are no adequate and well-controlled studies in women during lactation.

Pediatric use

Safety and effectiveness of Seldane in children below the age of 12 years have not been established. General

Consideration should be given to potential anticholinergic (drying) effects in patients with lower airway disease, including asthma.

\section{ADVERSE REACTIONS}

Experience from clinical studies, including both controlled and uncontrolled studies involving more than 2,400 patients who received Seldane, provides information on adverse experience incidence for periods of a few days up to six months. The usual dose in these studies was $60 \mathrm{mg}$ twice daily, but

in controlled clinical studies using the recommended dose of $60 \mathrm{mg}$ b.i.d., the incidence of reported adverse effects in patients receiving Seldane was similar to that reported in patients receiving placebo. (See Table below.)

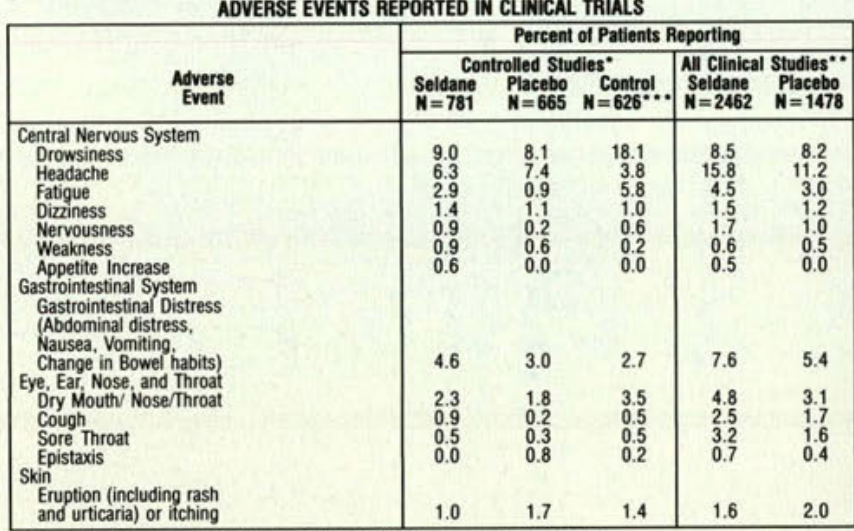

"Duration of treatment in "CONTROLLED STUDIES" was usually 7-14 DAYS.

"Duration of treatment in "ALL CLINICAL STUDIES" was up to 6 months.

CONTROL DRUGS: Chlorpheniramine (291 patients), d-Chlorpheniramine (189 patients), Clemastine (146 patients)

In addition to the more frequent side effects reported in clinical trials (See Table), adverse effects have been reported at a lower incidence in clinical trials and/or spontaneously during marketing of Seldane that warrant listing as possibly associated with drug administration. These include: alopecia, (hair loss or thinning), anaphylaxis, angioedema, arrhythmia (including ventricular tachyarrhythmia), bronchospasm, confusion, depression, galactorrhea, hypotension, insomnia, menstrual disorders (including dysmenorrhea), musculoskeletal symptoms, nightmares, palpitation, paresthesia, photosensitivity, prolonged QT interval, seizures, sweating, syncope, tachycardia, tremor, urinary frequency, and visual disturbances. In clinical trials, several instances of mild, or in one case, moderate transaminase elevations were seen in patients receiving Seldane. Mild elevations were also seen in placebo treated patients. Marketing experiences include isolated reports of jaundice, cholestatic hepatitis, and hepatitis: in most cases available information is incomplete. In neither the clinical trials nor marketing experience is a causal relationship of liver abnormalities to Seldane use clear.

OVERDOSAGE

Information concerning possible overdosage and its treatment appears in Full Prescribing Information. DOSAGE AND ADMINISTRATION

The usual dosage for adults and children 12 years and older is $60 \mathrm{mg}$ ( 1 tablet) twice daily. Product Information as of June, 1988

MERRELL DOW PHARMACEUTICALS INC.

Subsidiary of The Dow Chemical Company

Cincinnati, Ohio 45215, U.S.A.

Merrell Dow

PRINTED IN U.S.A.

References: 1. Kemp JP, Buckley CE, Gershwin ME, et al: Multicenter, double-blind, placebo-controlled trial of terfenadine in seasonal allergic rhinitis and conjunctivitis. Ann Allergy 1985:54:502-509. 2. Backhouse CI, Brewster BS, Lockhart JDF, et al: Terfenadine in allergic rhinitis. A comparative trial of a new antihistamine versus chlorpheniramine and placebo. Practitioner 1982:226:347-348, 351. 3. Buckley CE, Buchman E, Falliers CJ, et al: Terfenadine treatment of fal

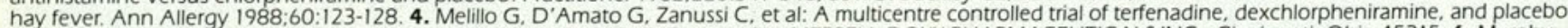
in allergic rhinitis. Arzneim-Forsch/Drug Res 1982:32:1202-1203. 5. Data on file, MERRELL DOW PHARMACEUTICALS INC., Cincinnati, Ohio 45215. 6. Murphy-

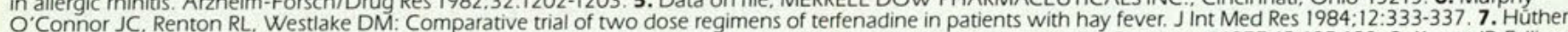

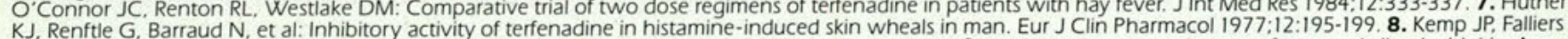

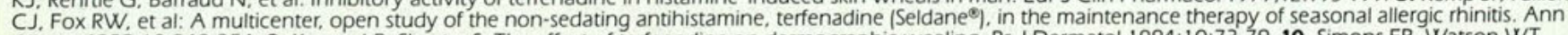
Allergy 1988:60:349-354. 9. Krause LB, Shuster S: The effect of terfenadine on dermographic wealing. Br J Dermatol 1984:10:73-79. 10. Simons FR, Watson WT, Simons KJ: Lack of subsensitivity to terfenadine during long-term treatment. J Allergy Clin Immunol 1988;82:1068-1075. 
1. Kramer JR, Hertzer NR: Coronary atherosclerosis in patients undergoing elective abdominal aortic aneurysm resection, in Vidt DG (ed): Cardiovascular Therapy. Philadelphia, FA Davis Co, 1982, pp 143-152. 2. Hertzer NR: Fatal myocardial infarction following abdominal aortic aneurysm resection: Three hundred forty-three patients followed 6-11 years postoperatively. Ann Surg 1980;192:667-673.

3. Tomatis LA, Fierens EE, Verbrugge GP: Evaluation of surgical risk in peripheral vascular disease by coronary arteriography: A series of 100 cases. Surgery 1972;429-435.

4. Edwards WH, Mulherin JL Jr, Walker WE: Vascular reconstructive surgery following myocardial revascularization. Ann Surg 1978;187:653657.

5. Hertzer NR, Beven EG, Young JR, et al: Coronary artery disease in peripheral vascular patients: A classification of 1000 coronary angiograms and results of surgical management. Ann Surg 1984;199:223233.

6. Brown OW, Hollier LH, Pairolero PC, et al: Abdominal aortic aneurysm and coronary artery disease. Arch Surg1981;116:1484-1488.

7. Diehl JT, Cali RF, Hertzer NR, et al: Complications of abdominal aortic reconstruction: An analysis of perioperative risk factors in 557 patients. Ann Surg 1983;197:49-56.

8. De Bakey ME, Crawford ES, Cooley DA, et al: Aneurysm of the abdominal aorta: Analysis of results of graft placement therapy one to eleven years after operation. Ann Surg 1964;160:622-639.

9. Darling RC, Brewster DC: Elective treatment of abdominal aortic aneurysms. World J Surg 1980;4:661-667.

10. Volpetti G, Barker CF, Berkowitz H, et al: A twenty-two year review of elective resection of adominal aortic aneurysms. Surg Gynecol Obstet 1976;142:321-324.

11. Thompson JE, Hollier LH, Patman RD, et al: Surgical management of abdominal aortic aneurysms: Factors influencing mortality and morbidity--a 20-year experience. Ann Surg 1975;181:654-661.

12. Crawford ES, Saleh SA, Babb JW, et al: Infrarenal abdominal aortic aneurysm: Factors influencing survival after operation performed over a 25-year period. Ann Surg 1981;193:699-709.

13. Gardner RJ, Lancaster JR, Tarnay TJ, et al: Five year history of surgically treated abdominal aortic aneurysms. Surg Gynecol Obstet 1970;130:981-987.

14. Gardner RJ, Gardner NL, Tarnay TJ, et al: The surgical experience and a one to sixteen year follow-up of 277 abdominal aortic aneurysms. Am J Surg 1978;135:226-230.

15. Pasch AR, Ricotta JJ, May AG, et al: Abdominal aortic aneurysm: The case for elective resection. Circulation 1984;70(supp I):1-4.

16. Whittemore AD, Clowes AW, Hechtman HB, et al: Aortic aneurysm repair: Reduced operative mortality associated with maintenance of optimal cardiac performance. Ann Surg 1980;192:414-421.

17. Hicks GL, Eastland MW, DeWeese JA, et al: Survival improvement following aortic aneurysm resection. Ann Surg 1975;181:863-869.

18. May AG, DeWeese JA, Frank I, et al: Surgical treatment of abdominal aortic aneurysms. Surgery 1968;63:711-721.

19. Stokes J, Butcher HR: Abdominal aortic aneurysms: Factors influencing operative mortality and criteria of operability. Arch Surg 1973;107:297-302.

20. Treiman RL, Levine KA, Cohen JL, et al: Aneurysmectomy in the octogenarian: A study of morbidity and quality of survival. Am J Surg 1982;144:194-197.

21. Chang RC, Smith JL, Rahbar A, et al: Abdominal aortic aneurysms: A comparative analysis of surgical treatment of symptomatic and asymptomatic patients. Am J Surg 1978;136:705-708.
22. Steen PA, Tinker JH, Tarhan S: Myocardial reinfarction after anesthesia and surgery. JAMA 1978;239:2566-2570.

23 O'Donnell TF Jr, Darling RC, Linton RR: Is 80 years too old for aneurysmectomy? Arch Surg 1976;111:1250-1257.

24. Szilagyi DE, Smith RF, DeRusso FJ, et al: Contribution of abdominal aneurysmectomy to prolongation of life. Ann Surg 1966;164:678699 .

25. Darling RC, Messina CR, Brewster DC, et al: Autopsy study of unoperated abdominal aortic aneurysms: The case for early resection. Circulation 1977;56(suppl 2):161-164.

26. Estes JE Jr: Abdominal aortic aneurysm: A study of one hundred and two cases. Circulation 1950;2:258-264.

27. Esselstyn CB Jr, Humphries AW, Young JR, et al: Aneurysmectomy in the aged? Surgey 1970;67:34-39.

28. Foster JH, Bolasny BL, Gobbel WG Jr, et al: Comparative study of elective resection and expectant treatment of abdominal aortic aneurysm. Surg Gynecol Obstet 1969;129:1-9.

29. Klippel AP, Butcher HR Jr: The unoperated abdominal aortic aneurysm. Am J Surg 1966;111:629-631.

30. David RF, Marks C, Bonneval P: A ten year institutional experience with abdominal aneurysms. Surg Gynecol Obstet 1974;138:591-594.

31. Sommerville RL, Allen EV, Edwards JE: Bland and infected arteriosclerotic abdominal aortic aneurysms: A clinicopathologic study. Medicine 1959;38:207-221.

32. Bernstein EF, Fisher JC, Varco RL: Is excision the optimum treatment for all abdominal aortic aneurysms: Surgery 1967;61:83-93.

33. Baker AG Jr: Long-term survival following abdominal aortic aneurysmectomy. JAMA 1970;212:445-450.

34. Baker WH, Munns JR: Aneurysmectomy in the aged. Arch Surg 1975;110:513-517.

35. Gravgaard E, Juul S, Albrechtsen O, et al: Prognosis and treatment of abdominal aortic aneurysm. Surg Gynecol Obstet 1980;151:777-780.

36. Wright IS, Urdaneta E, Wright B: Re-opening the case of the abdominal aortic aneurysm. Circulation 1956;13:754-768.

37. Hertzer NR: Myocardial ischemia. Surgery 1983;93:97-101.

38. Crawford ES, Morris GC Jr, Howell JF, et al: Operative risk in patients with previous coronary artery bypass. Ann Thorac Surg $1978 ; 26: 215-221$.

39. Hertzer NR, Young JR, Kramer JR, et al: Routine coronary angiography prior to elective aortic reconstruction: Results of selective myocardial revascularization in patients with peripheral vascular disease. Arch Surg 1979;114:1336-1344.

40. McCollum CH, Garcia-Rinaldi R, Graham JM, et al: Myocardial revascularization prior to subsequent major surgery in patients with coronary artery disease. Surgery 1977;81:302-304.

41. Szarnicki RJ, Green GE, Kemp HG: Coronary artery bypass surgery-prophylaxis prior to resection of abdominal aortic aneurysm. NY State $J$ Med 1971;15:2196-2199.

From the Department of Cardiothoracic Surgery, PresbyterianUniversity of Pennsylvania Medical Center, Philadelphia, 19104.

Reprint requests to Dr Haas, Suite 112, 400 Middletown Blvd, Langhorne, PA 19047. 


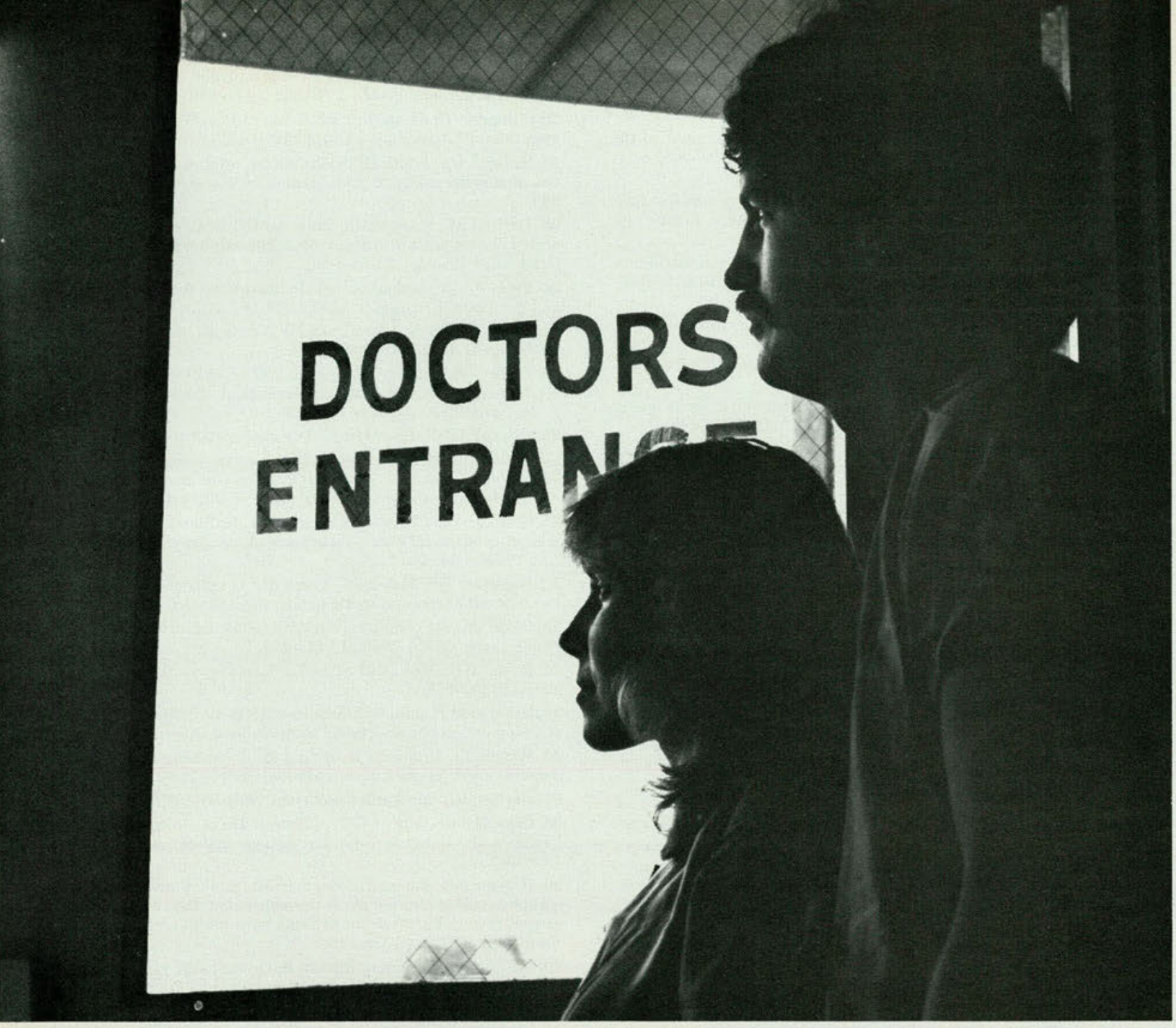

Education ... that's

what it's all about at

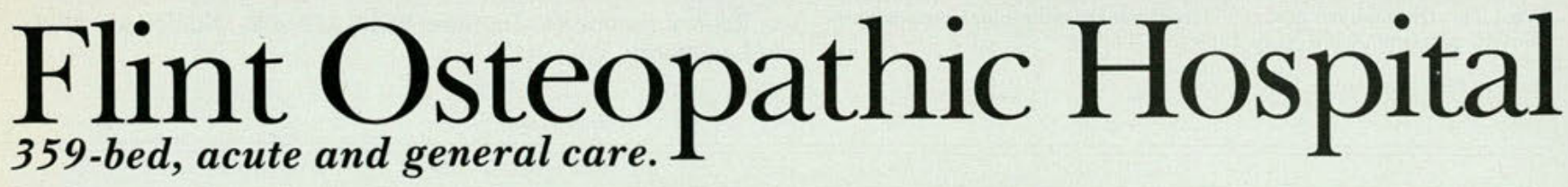

\section{Residencies}

- Anesthesia

- Family Practice

- Gastroenterology

- Internal Medicine

- Obstetrics/Gynecology

- Ophthalmology

- Orthopedics

- Otorhinolaryngology

- Pathology

- Pulmonary

- Radiology

- Surgery

- Urology

\section{Fellowships}

- Medical Diseases of the Chest

- Gastroenterology

One-year rotating internships

Student externships

Monthly Congdon lecture

series

Daily guest lectures \&

Morning reports

Journal Clubs
Christopher T. Meyer, D.O.

Vice President of Medical Education

Dennis V. DeSimone, D.O.

Director of Medical

Education 